\title{
Effect of Melatonin on some Biochemical Parameters in D-galactose Induced Aging in Rats
}

\author{
Enas O. Al-babily* Fadwa KH. Tawfeeq \\ Department of Physiology/College of Veterinary Medicine / University of Mosul \\ E-mail: babiliea99@yahoo.com
}

(Received 12\11\2019; Accepted 19\1\2020)

\section{DOI: $\underline{\text { 10.33899/rjs.2020.164473 }}$}

ABSTRACT

The current research investigates the main physiological and potent antioxidant roles of melatonin hormone in induced aging rats by D-galactose administration. This research includes 4 groups of male rat, Group 1:considered as a control group administered distilled water, Group 2: Dgalactose induced aging by administration of $(300 \mathrm{mg} / \mathrm{kg} \mathrm{B.Wt} \mathrm{.S.C.)} \mathrm{for} 15$ weeks, Group 3: administered melatonin hormone $(10 \mathrm{mg} / \mathrm{kg}$ B.wt. orally) for 15 weeks, Group 4: induced aging by D-galactose $(300 \mathrm{mg} / \mathrm{kg}$ B.wt .S.C.)+melatonin hormone $(10 \mathrm{mg} / \mathrm{kg}$ B.wt. orally) for 15 weeks. Results Body and brain weight is decreased in the induced aging rats. Advanced glycation end products (AGEs), Advanced oxidation protein products (AOPP) and thiobarbituric acid reactive substances (TBARS) is increased significantly in the D- galactose aged rats compared with control group accompanied with significant decrease in Superoxide dismutase (SOD) and Glutathione (GSH) level induced aging rats compared with control rat group. Melatonin hormone could effectively attenuates these alterations. conclusion: melatonin hormone administration counteracted the accelerated induced aging process by D-galactose in rats which may be due to its effects on antioxidant enhancing activity and protect the cell from lipid and protein oxidation.

Keywords: Aging, D- galactose, Melatonin hormone.

\section{INTRODUCTION}

Senecences (Aging) is a biological process which was accompanied by oxidative stress in the cell and the tissue in addition, aging enhanced body vulnerability to cognitive dysfunction and impairment in physical, mental and social activities (He et al., 2013; Kumar et al., 2011). The imbalance between the free radicals and antioxidant called oxidative stress, lead to produce impairment of various bio molecular processes and can lead to the accumulation of the damage over time (Stier et al., 2012). Aging process is subjected to quantitative modification by many factors such as genetic and environmental factors (Culter and Mattson, 2006). One model to understand the mechanism of aging is the use of chronic administration of D-galactose (D-gal) (Zhang et al., 2007 ab), as D-galactose accelerates aging in rodents (Cui et al., 2006).

D-galactose is a reducing monosaccharide present in very small quantities in the body (Cardoso et al., 2015). D-gal can be changed into glucose when present in normal concentration (Lei et al., 2008). An oversupply of D-gal can lead to conversion to D-galacto-hexodialdose and hydrogen peroxide and to the galactitol by the action of aldose reductase (Ho et al., 2003), the accumulation of these products in the cell caused osmotic and oxidative stress that can account for aging process acceleration (Kumar et al., 2011).

Melatonin ( $N$-acetyl-5-methoxy tryptamine) a hormone secreted from pineal gland with multiple functions (Shen et al., 2002). Melatonin is a free radical scavenger and is the primary antioxidant defender against reactive hydroxyl radicals (Barlow-Walden et al.,1995; Tan Dx et al., 1993). Melatonin exerts multiple beneficial effects on age-related physiological functions, which 
include metabolic sensing, modulation and proliferation of mitochondria, anti-oxidative protection of biomolecules and anti-inflammatory actions (Hardeland, 2013).

The aim of present study is to investigate the anti-aging effects of melatonin on some biochemical and oxidative stress parameters in the D-galactose induced aged rats and to explore the associated mechanism.

\section{MATERIAL AND METHODS}

All the steps of the experiment were performed in the animal house of the college of veterinary medicine/ University of Mosul. In this study, 24 male rats (4 months old) weight 200$250 \mathrm{~g}$ obtained from University of Baghdad were included, the rats maintained in cages with free access to water and food and with a 12/12 hour light -dark cycle and controlled temperature. The rats were divided randomly into four groups (6 animals per each) and treated as follows:

1- control group

Rats were given distilled water by intubation and subcutaneous injection daily .

2- induced aging group Rats injected with D-galactose $300 \mathrm{mg} / \mathrm{kg}$ body weight subcutaneously daily for 15 weeks.

3- melatonin group Rats daily drenched with melatonin orally $10 \mathrm{mg} / \mathrm{kg}$ body weight by gavage needle for 15 weeks.

4- D-galactose +melatonin group

Rats of this group daily injected by D-galactose subcutaneously $300 \mathrm{mg} / \mathrm{kg}$ body weight and melatonin orally drenched $10 \mathrm{mg} / \mathrm{kg}$ body weight for 15 weeks.

\section{Collection of Blood samples :}

At the end of the experiment, rats were weighted and anaesthetized by ether, blood were obtained from retro-orbital plexus from eye orbital sinus by using heparinized capillary tube. Serum samples were obtained by centrifuging whole blood at $3000 \mathrm{rpm}$ for 15 minutes and the supernatants were transferred into epindrof tubes and kept at $-20^{\circ} \mathrm{C}$ for biochemical tests analysis. Rats were dissected and fresh brain, heart, liver tissue were extracted to record organs weight.

\section{Estimation of serum advanced glycation end products (AGEs) and super oxide} dismutase(SOD) concentration

Serum level of the AGEs and SOD activity were assessed by using enzyme- linked immunosorbent assay(ELISA), two kits used (Al-Shkairate establishment for medical supply, Jordon, Catalogue No (AGEs): RDEER0268, (SOD): RDEER0332).

\section{Estimation of serum advanced oxidative protein products (AOPP)}

Spectrophotometric determination of AOPP was performed by using the modified methods of Witko-Sarsat's (Witko-Sarsat et al., 1996).

\section{Estimation of serum glutathione (GSH).}

Serum glutathione (GSH) was estimated according to the modified method described by (Sedlak and Linsay, 1968).

\section{Estimation of serum thiobarbituric acid reactive substance (TBARS).}

Lipid peroxidation end products in cells and tissue determined by thiobarbituric acid -reactive substance(TBARS) in serum were estimated according to (Brown and Kelly, 1996).

\section{Statistically analysis}

The data analyzed by using one -way analysis of variance, then were followed by using Duncan's multiple range test(SPSS version 24,USA) to evaluate differences between groups means. The results of experiment were expressed as mean \pm standard error. Values are considered significantly different at $(\mathrm{P} \leq 0.05)$. 


\section{1- Body weight and relative organ weight}

\section{RESULTS AND DISCUSSION}

At the end of treatment period, significant weight loss $(\mathrm{P} \leq 0.05)$ was observed in induced aging group compared to control with no significant difference in other treatments (Table 1). Melatonin improved aged treated body weight compared with aged group ( $\mathrm{P} \leq 0.05)$.

The brain relative weight decreased significantly $(\mathrm{P} \leq 0.05)$ in aged rats and melatonin treated groups compared with control group (Table 1). No significant difference in liver and heart relative weight all the experiment groups (Table 1). The free radical theory is one of the most popular aging theories, by accumulated free radicals such as reactive oxygen species causing lipid, DNA, protein and tissue damage in organisms (Harman, 2003). The decrease in body weight and brain could be attributed to aging and loss of muscle mass (Stefanova et al., 2014; Baeta-corral et al., 2018). This agreed with Liu et al. (2018) that D-gal (200 mg/kg B. WT. S.C.) causes decrease in body weight and brain and D-gal injection causes atrophy of brain tissue, the decrease in body weight of melatonin treated rats group may be due to its ability to reduce appetite, food intake. and inhibit fat accumulation in fat tissue of obese animals (Piccinetti et al., 2010; Cardinali et al., 2011) Perhaps the reason may be that these organs are very sensitive and are considered to be one of the most indications of an increase in the level of chemicals in the body, such as drug poisoning, which causes the appearance changes (Piao et al., 2013). Therefore, many internal organs in the body show weight loss and atrophy (Tandon and Vohra, 2006).

Table 1 : Effects of melatonin hormone treatment on the body weight and organ relative weight

\begin{tabular}{|c|c|c|c|c|}
\cline { 3 - 5 } \multicolumn{2}{c|}{} & \multicolumn{3}{c|}{ Organ relative weight (mg/100 gm B.WT.) } \\
\hline Groups & Body weight(g) & Heart & liver & Brain \\
\hline Control & $320.97 \pm 15.43 \quad$ a & $350.05 \pm 14.05$ a & $3576.1 \pm 127.34 \quad$ a & $702.17 \pm 32.28$ a \\
\hline Induced aging (D-gal) & $248.67 \pm 18.84 \quad$ b & $383.50 \pm 24.25 \quad$ a & $2971.47 \pm 247.42 \mathrm{a}$ & $593.73 \pm 20.46 \mathrm{~b}$ \\
\hline Mel & $284.17 \pm 7.5 \quad$ ab & $395.90 \pm 19.67 \mathrm{a}$ & $3450.80 \pm 186.53 \mathrm{a}$ & $614.80 \pm 18.35 \mathrm{~b}$ \\
\hline D-gal +Mel & $277.17 \pm 12.50$ ab & $369.12 \pm 30.39 \mathrm{a}$ & $3462.33 \pm 203.73 \mathrm{a}$ & $588.07 \pm 10.60 \mathrm{~b}$ \\
\hline
\end{tabular}

\section{2- Effect of melatonin hormone treatment on advanced glycation end products(AGEs) concentration.}

AGEs concentration increased significantly $(\mathrm{P} \leq 0.05)$ in the induced aging group (D-gal) compared to control group, melatonin and Melatonin $+\mathrm{D}$ galactose groups Fig. (1). Melatonin and melatonin+ d-galactose group not differ from control group. Thus treated melatonin hormone restored AGEs concentration to control value Fig. (1). Advanced glycation end products (AGEs) conc. increased in the induced aged rat (D-gal). AGEs increased during aging and have been regarded as one of the senescence's markers (Frimat et al., 2017). The glycation process is initiated by a chemical reaction between reactive carbonyl group of sugar or an aldehyde with a free amino group of a protein by forming inter-mediate products leading to the formation of AGEs (Kim et al., 2017). AGEs are highly accumulated in tissues and organs in numerous age-related pathological mannar such as diabetes, renal failure, inflammation (Ott et al., 2014). These toxic (glycotoxins) implicated in cell dysfunction espically in diabetic and older organisms (Kim et al., 2017). 


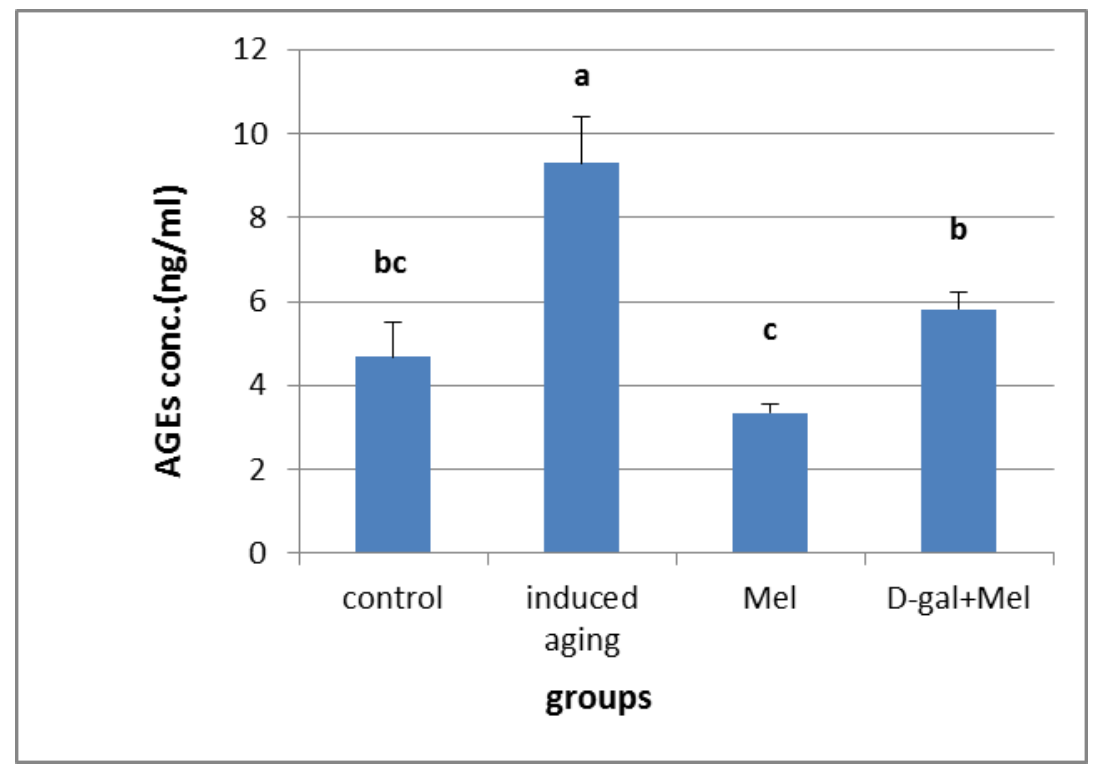

Fig. 1: Effect of melatonin hormone treatment on (AGEs) concentration.

\section{3- Effect of melatonin hormone treatment on super oxide dismutase (SOD) concentration .}

SOD concentration significantly decrease $(\mathrm{P} \leq 0.05)$ in the aging group (D-gal) and melatonin group compared with control group Fig. (2), in addition, melatonin failed to return SOD concentration at D-gal +melatonin group to control value but defer than control Fig. (2). Enzymatic antioxidants such as SOD and non-enzymatic GSH can neutralize the reactive oxygen species (ROS) and prevent further injury to the cell. In the present research melatonin enhanced serum antioxidant activity of D-galactose - induced aging rats. In which SOD conc. decrease significantly which is in consistent with one proposed mechanism of D-galactose senescence induction by increased production of oxidants with changes in the antioxidant enzymes activity and accumulation of oxidative damage (Wei et al., 2005; He et al., 2009). These results were agreed with the previous studies which confirmed the decrease in liver and kidney SOD activity in the mature rats treated with D-galactose (Hadzi -Petrusher et al., 2015), also it agreed with Ahangarpour et al. (2016) who noticed that D-galactose treatment causes a decrease in SOD concentration in the female rat administered (500 mg/kg B.Wt. S.C. for 45 day).

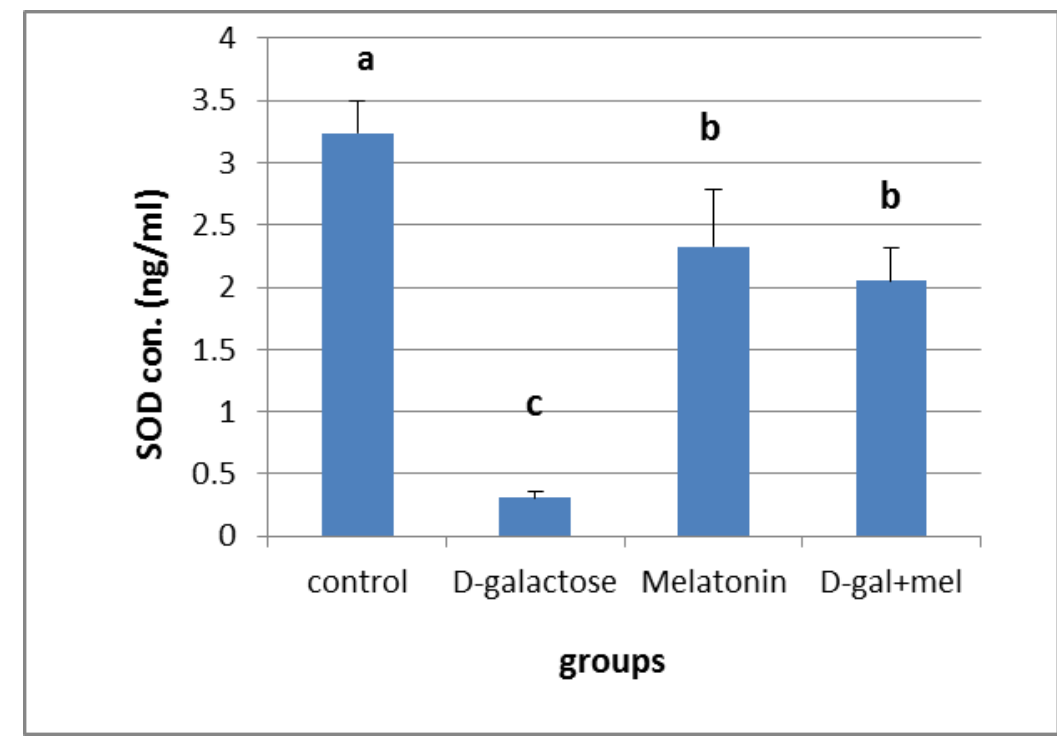

Fig. 2: Effect of melatonin hormone treatment on SOD concentration 4- Effect of melatonin hormone on advanced oxidation protein product (AOPP) concentration 
AOPP concentration in the induced aging rat was increased significantly $(\mathrm{P} \leq 0.05)$ in compared to control group Fig. (3), no significant differences in its concentration between melatonin treated group and control group Fig. (3). Aged rats treated with melatonin showed a significant $(\mathrm{P} \leq 0.05)$ decrease in AOPP concentration compared with aging group Fig. (3). So melatonin decrease significantly $(\mathrm{P} \leq 0.05)$ AOPP conc. as compared to aging group in both melatonin and D-gal +melatonin group but not returned to control value. AOPP is a marker of lipid peroxidation increased significantly in the aging-induced rats (D-gal group). AOPP is a marker of oxidative stress associated with age (Zhang et al., 2011).

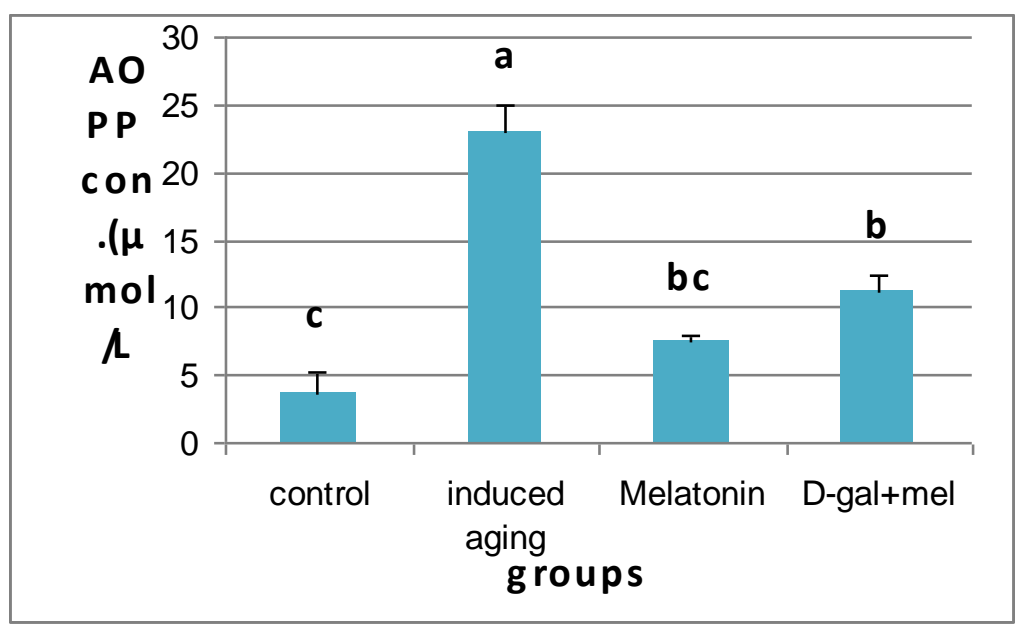

Fig. 3: Effect of melatonin hormone treatment on AOPP concentration

\section{5- Effect of melatonin hormone treatment on Glutathione (GSH) concentration.}

GSH level decreased significantly $(\mathrm{P} \leq 0.05)$ in the induced aging group compared to control Fig. (4) and significantly increased $(\mathrm{P} \leq 0.05)$ in melatonin treated and melatonin $+\mathrm{D}-$ galactose groups reach to its concentration in control group Fig. (4). So melatonin treated restored GSH concentration to control value, the GSH contribute substantially to intracellular antioxidant defense mechanism, decrease in anti-oxidant activity which result in a reduced protection against oxidative stress produced by ROS generation, D-galactose hastening effect on cell senescence and oxidative stress might be responsible for its apparent aging effect (Shen et al., 2002) and similar to those seen by Yanar et al., (2011) who noticed that D-galactose rat injection daily at a dose $(60 \mathrm{mg} / \mathrm{kg} \mathrm{b.W.T.}$ for 6 week) reduced in glutathione concentration, and Uzun et al., (2013) found that GSH concentration decreased significantly in 24 month old male and female rats than that of 6 months age. In the present research, we found that melatonin $(10 \mathrm{mg} / \mathrm{kg})$ significantly ameliorated the SOD and GSH concentration, because melatonin plays an indirect roles in preventing free radicals by means of its ability to stimulate several important antioxidant enzymes, in addition to both pharmacological and physiological roles of melatonin to stimulates both the mRNA level and the activities of anti-oxidative agent (Pablos et al., 1997; Kotler et al.,1998). This agreed with Shen et al.,(2002) who found that antioxidant activity of melatonin $(0.1,1$ and $10 \mathrm{mg} / \mathrm{kg})$ for 3 month to mice treated with D-galactose increase concentration of SOD,GSH and reduce the concentration of TBARS. AOPP is a protein oxidation biomarker, and structural basis of the cells is protein forms which likely to be oxidized due to imbalance induced via D-galactose administration. This is in agreement with Aydin et al., (2018) who confirmed that D-gal administration to rat $(60 \mathrm{mg} / \mathrm{kg}$ B.Wt i.p. for 6 weeks $)$ causes increase in AOPP concentration, also in agreement with Yanar et al., (2011) who noticed that D-galactose administration causes rat aging induction by significant increase in AOPP concentration. 


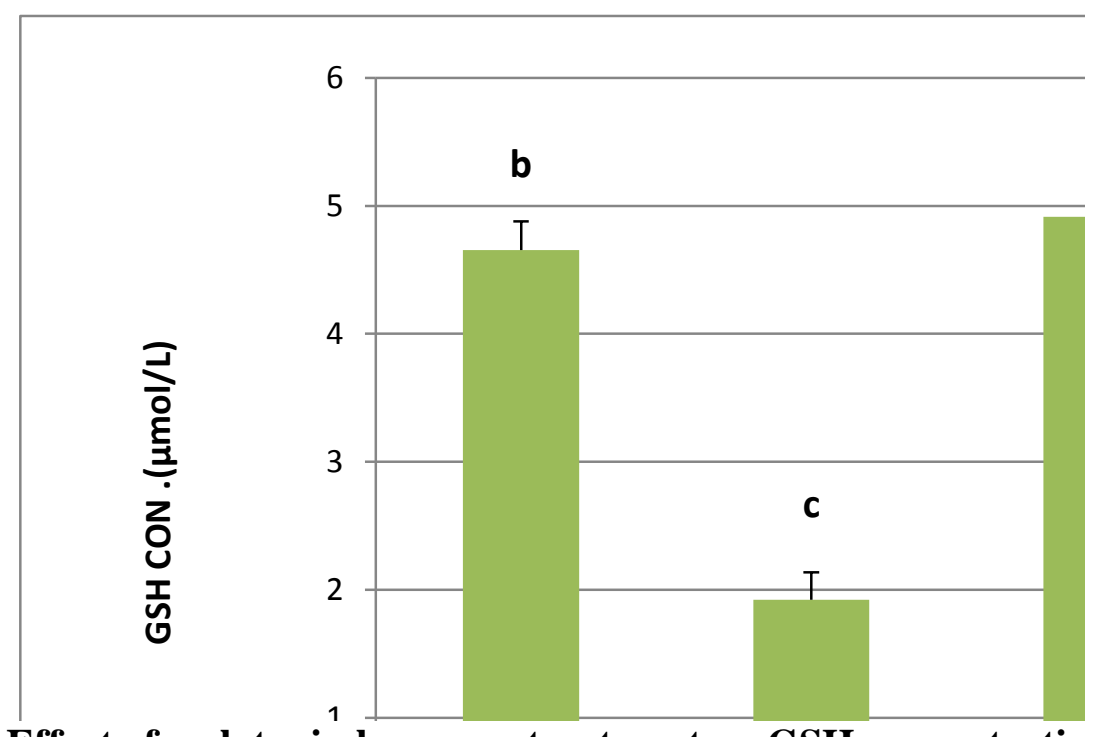

Fig .4: Effect of melatonin hormone treatment on GSH concentration

\section{6- Effect of melatonin hormone treatment on TBARS concentration}

TBARS concentration is increased significantly $(\mathrm{P} \leq 0.05)$ induced aging group compared with control group while Melatonin hormone alone treated decrease significantly TBARS conc. Fig (5). as compared with induced aging group Fig. (5). with no significant changes in its concentration compared to control group Fig. (5). TBARS a lipid oxidation biomarkers is increased significantly in the treatment by $\mathrm{D}$-galactose induced aging group in this research. D-galactose causes increase malondialdehyde (MAD) level, the MDA level is a major marker of the lipid peroxidation in aging tissue, MDA destroys the unsaturated fatty acids in cell membranes so structure and function of cell are changed in lipid peroxidation of the mitochondrial, lysosomal and plasma membrane (Celik et al., 2004). These results are in agreement with Sun et al.,(2013) who confirmed that the D-galactose treatment induce aging because by increase MDA content with decrease in the activity of SOD and GSH concentration. Also in agreement with Shen et al.,(2002) who noticed that D-galactose $(25 \mathrm{mg} / \mathrm{kg} \mathrm{B}$.WT.S.C.) for 3 month increase level of TBARS in 6 month old BALB/C mice, and the study of Zhong et al., (2016) who noticed that D-galactose $(100 \mathrm{mg} / \mathrm{kg}$ B.WT. orally for 8 weeks) causes increase in MDA concentration in 3 month mice old. The melatonin hormone can reduce MDA in aged induced rats, this indicated that melatonin may protect the cells from the oxidative damage induced by D-galactose as a free radical scavenger and antioxidant (Reiter, 1997). and is protective brain against oxidative deterioration (Reiter,1998).

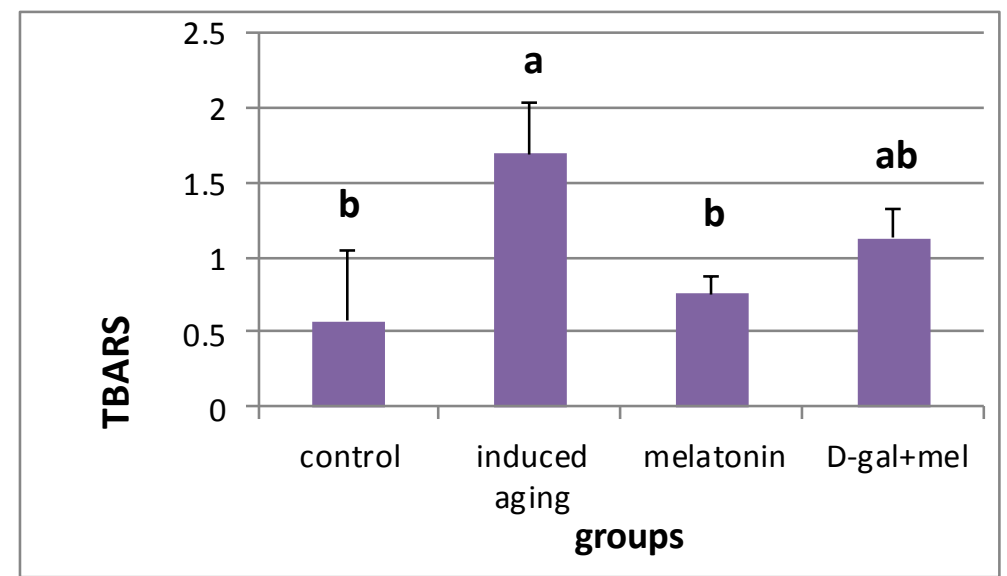

Fig. 5: Effect of melatonin hormone treatment on TBARS concentration 


\section{CONCLUSION}

we concluded that melatonin treatment $(10 \mathrm{mg} / \mathrm{kg})$ significantly reduce oxidative stress induction by D-galactose ameliorated antioxidant activities in male rat treated with D-galactose, such as GSH, SOD and the AGEs, AOPP and TBARS, due to its potent free radical scavengers effect and potent antioxidant effect.

\section{REFERENCE}

Ahangarpour, A.; Najimi, S.A.; Farbood, Y. (2016). Effects of Vitex agnus -castus fruit on sex hormones and antioxidant indices in a D-galactose induced aging female mouse model. $J$. Chinese Medical Association., 79, 589-596.

Aydin, S.; Yanar, K.; Simsek, B.; Cebe, T.; Sitar, M.E.; Belce, A.; Cakatay, U.(2018). Galactose induced aging model in rat testicular tissue. J. College of Physicians and Surgeons Pakistan., 28(7), 501-504.

Baeta-Corral, R.; Castro-Fuentes, R.; Gimenez-LLORT, L. (2018). Sexual dimorphism in the behavioral response and the immunoendocrine status in D-galactose induced aging. $J$. Gerontol. Series A. Biol. Sci. and Med. Sci.,73(9),1147-1157.

Barlow -walden, L.R.; Reiter, R.J.; Abe, M.; Pablos, M.; Menendez-Pelaez, A.; Chen, L.D.; Poeggeler, B. (1995). Melatonin stimulates brain glutathione peroxidase activity. Neurochem. Int., $26,497-502$.

Brown, R.K. ; Kelly, F.J. (1996). "Peroxides and other Products in Free Radicals a Practical Approach". Oxford University Press, Oxford, pp.119-131.

Cardinali, D.P.; Pagano, E.S.; Scacchi Bernasconi, P.A.; Reynoso, R.; Scacchi, P. (2011). Disrupted chronobiology of sheep and cytoprotection in obesity: possible therapeutic value of melatonin. Neuro. Endocrinol. Lett.,32, 588-606.

Cardoso, A.; Magano, S.; Marrana, F.; Andrade, J.P. (2015). D-galactose high -dose administration failed to induce accelerated aging changes in neurogenesis, anxiety and spatial memory on young male wistar rat. Rejuevnation Res., 18(6), 497-507.

Celik, O.; Turkoz, Y.; Hascalik, S.; Hascalik, M.; Cigremis, Y.; Mizrak, B. (2004). The protective effect of caffeic acid phenethyl ester on ischemia-reperfusion injury in rat overy. Eur. $J$. O.bstet. Gynecol. Reprod. Biol.,117,183-8.

Cui,X.; Zuo, P.; Zhang, Q.; Li, X.; Hu, Y.; Long, J.; Packer, L.; Liu, J. (2006). Chronic systemic dgalactose exposure induces memory loss, neurodegeneration, and oxidative damage in mice: protective effects of R-alpha-lipoic acid. J. Neurosci. Res.,84,647-54.

Cutler, R.G.; Mattson, M.P. (2006). The adversities of aging. Ageing. Res. Rev., 5,221-238.

Frimat, M.; Daroux, M.; Litke, R. (2017). Kidney, heart and brain: three organs targeted by ageing and glycation. Clin. Sci.(Lond), 131,1069-92.

Hadzi-Petrushev , N.; Stojkovski, D.; Mitrov, D.; Mladenov, M. (2015). D-galactose induced changes in enzymatic antioxidant status in rats of different ages. Physiol. Res., 64,61-70.

Hardeland, R. (2013). Melatonin and the theories of aging. A critical appraisal of melatonin's role in anti-aging mechanisms. J. Pineal Res., 55,325-356.

Harman, D. (2003). The free radical theory of aging. Antioxid. Redox. Signal., 5,557-561.

He, L.Q.; Lu, J.H.; Yue, Z.Y.(2013). Autophagy in ageing and ageing associated disease. Acta. Pharmacol. Sin., 34, 60511.

He, M.; Zhao, L.; Wei , M.J.; Yao, W.F.; Zhao, H.S.; Chen, F.J. (2009). Neuroprotective effects of (-)-epigallocatechin-3-gallate on aging mice induced by D-galactose. Biol. Pharm. Bull., 32,55-60.

Ho, S.C.; Liu, J.H.; Wu, R.Y. (2003). Establishment of the mimetic aging effect in mice caused by D-galactose. Biogerontol., 4,15-18. 
Kim, C.S.; Park, S.; Kim, J. (2017). The role of glycation in the pathogenesis of aging and its prevention through herbal products and physical exercise. J. Exerc. Nutrition Biochem.,21(3),055-061.

Kotler, M.; Rodriquez, C.; Sainz, R.M.; Antolin, I.; Menendez-Pelaez, A. (1998). Melatonin increase gene expression for antioxidant enzymes in rat brain cortex. J. Pineal Res., 24,8389.

Kumar, A.; Prakash, A.; Dogra, S. (2011). Centella asiatica attenuates d-galactose - induced cognitive impairment .oxidative and mitochondrial dysfunction in mice. Int. J. Alzheimers Dis., 1-9.

Lei, M.; Hua, X.; Xiao M.; Ding, J.; Han, Q.; Hu, G. (2008). Impairments of astrocytes are involved in the D-galactose -induced brain aging. Biochem. Biophys. Res. Commun., 369,1082-7.

Liu, J.; Chen, D.; Wang, Z.; Chen, C.; Ning, D.; Zhao, S. (2018). Protective effect of walnut on Dgalactose-induced aging mouse model. Food Sci. Nutr.,1-8.

Ott, C.; Jacobs, K.; Haucke, E.; Navarrete Santos, A.; Grune, T.; Simm, A. (2014). Role of advanced glycation end products in cellular signaling. Redox Biol., 2,411-29.

Pablos, M.I.; Guerrero, J.M.; Ortiz, G.G.; Agapito, M.T.; Reiter, R.J. (1997). Both melatonin and a putative nuclear melatonin receptor agonist CGP 52608 stimulate glutathione peroxidase and glutathione reductase activities in mouse brain in vivo. Neuroendocrinal Lett.,18,354358.

Piao, Y.; Liu, Y.; Xie, X. (2013). Change trends of organ weight background data in sprague dawley rats at different ages. J. Toxicol. Pathol. 26,29-34.

Piccinetti, C.C.; Migliarini, B.; Olivotto, I.; Coletti, G.; Amici, A.; Carnevali, O.(2010). Appetite regulation :the central role of melatonin in Danio rerio. Horm. Behav., 58,780-5.

Reiter, R.J.(1997).Antioxidant action of melatonin. Adv. Pharmacol., 38,103-117.

Reiter, R.J.(1998).Oxidative damage in the central nervous system: protection by melatonin. Prog. Neurobiol.,56,359-384.

Sedlack, J.; Lindsay, R.H.(1968). Estimation of total, protein -bound, and non-protein sulfhydryl groups in tissue with Ellman's reagent. Analytical |Biochem., 25,192-205.

Shen, Y.X.; Xu, S.Y.; Wei, W.; Sun, X.X.; Yang, J.; Liu, L.H.; Dong, C. (2002). Melatonin reduces memory changes and neural oxidative damage in mice treated with D-galactose. J. Pineal Research, 32,173-178.

Stefanova, N.A.; Kohevnikova, O.S.; Vitovtov, A.O.; Maksimova, K.Y.; Logvinov, S.V.; Rudnitskaya, E.A.; korbobolina, E.E.; Muraleva, N.A. ; Kolosova, N.G. (2014). Senescense -accelerated OXYS rats: a model of age-related cognitive decline with relevance to abnormalities in Alzhemir disease. Cell cycle,13(6),898-909.

Stier, A.; Reichert, S.; Massemin, S.; Bize, P.; Criscuolo, F.(2012). Constraint and cost of oxidative stress on reproduction :correlative evidence in laboratory mice and review of the literature. Front. Zool .,9,1-11.

Sun, J.H.; Liu, Y.M.; Cao, T.; Ouyang, W.Q. (2013). Effect of kinetin on overy and uterus in dgalactose - induced female mouse model of aging. Sheng Li .Xue. Bao.,65,389-94.

Tan, D.X.; Chen, L.D.; Poeggler, B.; Manchester, L.C.; Reiter, R.J. (1993). Melatonin: A potent endogenous hydroxyl radical scavenger. Endocrine J., 1,57-60.

Tandon, S.; Vohra, V.K. (2006). Ageing; Current R\&D Highlights, January March.

Uzun, D.; Korkmaz, G.G.; Sitar, M.E.; Cebe, T.; Yanar, K.; Gakatay, U.; Aydin, S.(2013). Oxidative damage parameters in renal tissues of aged and young rats based on gender. Clinical Intervention in Aging., 8, 809-815.

Wei, H.; Li, L.; Song, Q.; Ai, H.; Chu, J.; Li, W.(2005). Behavioral study of the D-galactose induced aging model in C57BL/6Jmice. Behav. Brain Res., 157,245-251. 
Witko-Sarsat, V.; Friedlander, M.; Capeillere-Blandin C.; Khoa, T.; Nguyen, A.T.; Zingraff, J.; Jungers, P.; Descamps -Latscha, B. (1996). Advanced oxidation protein products as a noval marker of oxidative stress in uremia. Kidney Int.,49, 304-13.

Yanar, K.; Aydin, S.; Cakatay, U.; Mengi, M.; Buyukpmarbasili, N.; Atukeren, P.; Sitar, M.E.; Sonmez, A.; Uslu, E.(2011). Protein and DNA oxidation in different anatomic regions of rat brain in a mimetic ageing model. Basic and Clin. Pharmacol. Toxicol., 109, 423-433.

Zhang, H.X.; Yu, N.C.; Huang, G.F.; Shao, J.; Wu, Y.; Huang, H.; Liu, Q.; Ma,W.; Yi, Y.; Huang, H.(2007 a). Neuroprotective effects of purslane herb aqueous extracts against D-galactose induced neurotoxicity. Chem. Biol. Interact., 170,145-152.

Zhang, X.L.; Jiang, B.; Li, Z.B.; Hao, S.; An, L.J.(2007b). Catalpol ameliorates congnition deficits and attenuates oxidative damage in the brain of senescent mice induced by D-galactose. Pharmacol. Biochem. Behav.,88,64-72.

Zhang, Y.B.; Zhong, Z.M.; Hou, G.; Jiang, H .;Chen, J.T.(2011). Involvement of oxidative stress in age-related bone loss. J. Surg .Res.,169,37-42.

Zhong, L.; Huang, F.; Shi, H.; Wu, H.; Zhang, B.; Wu, X.; Wei, X.; Wang, Z.(2016).Qing' E formula alleviates the aging process in D-galactose - induced aging mice. Biomedical. Report., 5, 101-106.

\title{
تأثير الميلاتونين على بعض القياسات الكيموحيوية في الجرذان المستحثثة الثيخوخة بسكر الكالكتوز
}

\author{
الملخص \\ تهدف الدراسة الحالية إلى التعرف على الدور الفسلجي الرئيس والفعل المضاد للأكسدة لهرمون الميلاتونين في الجرذان \\ المستحدثة للثنيخوخة بسكر الكالكتوز. المواد وطرائق العمل: تضمنت الدراسة استخدام 4 مجاميع من ذكور الجرذان البالغة، \\ المجموعة الاولى اعتبرت كمجموعة سيطرة أعطيت الماء المقطر، المجموعة الثانية الجرذان المستحدثة للشيخوخة بسكر الكالكتوز \\ (300 ملغم / كغم من وزن الجسم عن طريق الحقن تحت الجلد ) لمدة 15 أسبوعا، المجموعة الثالثة جرعت الجرذان بهرمون \\ الميلاتونين (10 ملغم / كغم من وزن الجسم عن طريق الفم) لمدة 15 أسبوعا، المجموعة الرابعة جرذان المستحدثة للشيخوخة \\ بسكر الكالكتوز (300 ملغم/ كغ تحت الجلد)+ هرمون الميلاتونين (10 ملغم / كغم عن طريق الفم) لمدة 15 أسبوعا النتائج: \\ بينت نتائج التجربة وجود انخفاض معنوي في وزن الجسم والدماغ في جرذان المستحدثة للشيخوخة بسكر الكالكتوز ، زيادة معنوية

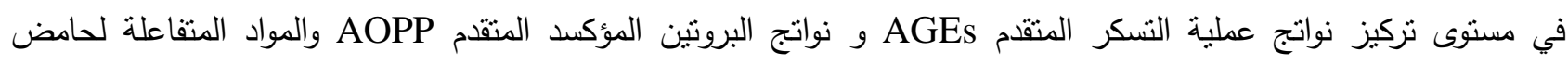

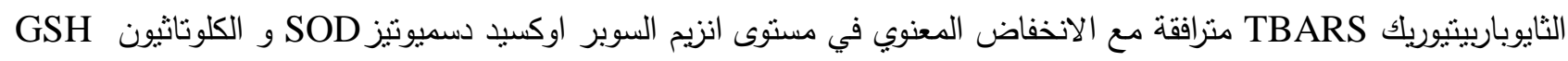 \\ في مجموعة الثيخوخة المستحدثة بسكر الكالكتوز مقارنة مع مجموعة السيطرة. هرمون الميلاتونين أدى إلى تغيير في المتغيرات \\ السابقة بشكل فعال. الاستتناج: أن إعطاء هرمون الميلاتونين يمكن ان يعدل من عملية التقدم بالعمر المستحدثة بسكر الكالكتوز \\ في الجرذان وذلك بسبب تأثيره الفعال المضاد للأكسدة وكذلك حماية الخلية من أكسدة البروتينات والدهون. \\ الكلمات الدالة: التقدم بالعمر ، سكر الكالكتوز، هرمون الميلاتونين.
}

